\title{
Determinants of the Size of the Government Expenditure: An Empirical Study on Bangladesh
}

\author{
Mahamuda Firoj ${ }^{1}$, Nair Sultana ${ }^{1} \&$ Farhana Sultana $^{2}$ \\ ${ }^{1}$ Faculty of Economics and Banking Department, International Islamic University Chittagong, Bangladesh \\ ${ }^{2}$ Student of MSS, International Islamic University Chittagong, Bangladesh \\ Correspondence: Mahamuda Firoj, Faculty of Economics and Banking Department, International Islamic \\ University Chittagong, Bangladesh. E-mail: fmahamudacu@gmail.com
}

Received: October 11, 2018

Accepted: October 29, 2018

Online Published: October 31, 2018

doi:10.5539/ijef.v10n11p149

URL: https://doi.org/10.5539/ijef.v10n11p149

\begin{abstract}
Analysis of the nature of government expenditure constitutes a central concern in economic literature. This is because many countries of the world consistently have increased the size of government expenditure. Bangladesh has done the same practice over the last few decades. There is a need to investigate the factors which determine the size of the public spending of Bangladesh. The error correction modeling technique for the short-run dynamic equation and ordinary least square (OLS) for long-run static equation are used over the period 1973 to 2016 to this purpose. The results of the short run dynamic equation and long-run static equation showed that external debt, real GDP, urbanization, tax, and non-tax government revenue positively influence the government expenditure where dependency on foreign aid and trade openness adversely affect it. The study recommends that the government should take proper step to expand the revenue base, stimulate the economic growth and reduce the external debt, and foreign aid.
\end{abstract}

Keywords: government expenditure, error correction model, OLS, determinants, revenue

\section{Introduction}

Fiscal functions of government are essential specifically for underdeveloped and developing countries because government expenditure creates a path to boost up their national output (Ukwueze, 2015). Over the years, the structure and size of the public sector regarding its expense have grown tremendously in many economies, especially after the $2^{\text {nd }}$ World War. The latest progress of the world economies is noticeable by the sustained extension of the national income and growing range of public spending. Notably, throughout the previous 60 years all the economies of the earth, tiny or immense, have practiced increasing government expenditure despite their political and economic conditions.

A higher number of researchers have to pay their concentration on perceptive the association between national income and government expenditure. According to the Keynesian hypothesis, government spending is an exogenous variable in economic growth (Keynes, 2018). On the other hand, Wagner (1892) observed that higher public spending is the usual outcome of growing GDP. However, many studies have empirically tested Wagner's Law and found the differing result for different economies.

To realize the reasons for the growth of government expenditure economists go back to the early Wagner (1892) and further begin with Downs (1957) in more present time. Government expenditure is habitually intended to plummet poverty in developing and underdeveloped countries. But if the spending fails to excite economic growth, it will not produce enough income to backing government expenditure in the subsequent periods or a gigantic size of government spending may create severe financial problems such as the massive budget deficit, slow economic growth, and deficit in the balance of payment. Avowed, most government expenditure has an unenthusiastic fiscal impact. During the last few decades, the government spending of Bangladesh has registered momentous rises which increase the budget deficit rapidly, but the growth of GDP also increase in parallel rate. Data show that in 2016 the government expenditure of Bangladesh raised by $29.5 \%$ from the level in 2015 . As a percentage of GDP, it illustrated $15.3 \%$ as contrasted with $13.5 \%$ in 2015, while the GDP growth rate was $7.11 \%$ and it outstripped the $6.6 \%$ growth rate recorded in 2015 (Bangladesh Bank, 2017). This study attempts to investigate the factors which determine the size of the government expenditure of Bangladesh. This paper is 
formed as follows. Section 2 furnishes a brief review of the relevant literature. Section 3 represents an overview of government expenditure of Bangladesh. Section 4 dwells the data characteristics, models and methodology used in estimation. Section 5 provides the empirical findings of the study with comprehensive analyses of the results while section 6 concludes the study.

\section{Literature Review}

In economic literature, there are primarily two contrasting views about the connection between economic growth and public spending. These are the Keynesian theory and Wagner's law. The Keynesian view states that higher government expenditure will root the higher economic growth, on the other hand, Wagner hypothesis implies that the expansion of a manufacturing country will be accompanied by an augmented allocate of public expenditure in the gross national output.

Most of the literature on government expenditure empirically examined the economic theories like Wagner or Keynesian law in different economics. Kolluri et al. (2000), using the historical data from 1960 to 1993 for 67 industrial countries estimated an error correction model and found that the national income has a significant short-run shock on government expenditure. Islam (2001) found a long-run equilibrium between the comparable size of public spending and per capita income in the US economy by using Johansen-Juseliuscointegration and exogenity test on the yearly dataset of 1929 to 1996. Almost the same result found by the study of Chang (2002) by using Johansen-Juseliuscointegration and error correction model on six economies covering the period 1951 to 1996. The study results implied that there exists the long-run affiliation between the national income and government expenditure in South Korea, Taiwan, Japan, the USA, and the UK but not for Thailand. Akitoby et al. (2006) tested Wagner's law in 51 developing nations by using the error correction model and found a stronger connection between government spending and national output. Lamartina and Zaghini (2011) also support the Wagner's law in 23 OECD countries by using panel cointegration analysis from 1970 to 2006 . An opposite result found by Folster and Henrekson (2001). By using econometric panel study from the sample of rich economies over the year 1970 to 1995, they originated an inverse relationship between public spending and economic enlargement.

Nyamongo et al. (2007) estimated the affiliation between government revenue and government expenditure in South Africa from 1994 to 2004. By using the VAR approach, they found that the government expenditure and government revenue are cointegrated which implies a long run relation between them.

Trade openness and foreign aid emphasize as essential determinants of government expenditure by various literature. Kimakova (2009), Rodric (1998) empirically investigate the impact of trade openness on the size of government spending. Rodric (1998) suggested that the enslavement on international trade raise the volatility of internal markets which create the necessity of social security provided by the government, in a study of 23 OECD countries. By using panel data linear regression on 87 developed and developing countries for the period of 1976 to 2003 Kimakova (2009) found that the age dependency, urbanization positively influence the government expenditure but trade openness significantly associated the size of the government expenditure. He also found that the population size negatively affects the government expenditure. Turan and Karakas (2016), from the dataset of 1970 to 2011 for South Korea and Turkey, found that a positive effect of trade openness on the government expenditure for South Korea but a negative influence in Turkey by using the ARDL approach of cointegration. Form the sample of some middle and lower income countries for the period of 1970 to 1999 Remmer (2004) used the ordinary least square with panel corrected standard error and found that the dependency on foreign aid boosts the growth of government spending. The study concluded that foreign aid has a stronger influence on government spending rather than the size of the population, age formation, trade openness, and per capita income.

From the data of 1972 to 2001 for 47 developing countries Mahdavi (2004) investigated that more substantial debt burden considerably increases the government expenditure. The study suggested that external debt altered the budget allocation where interest payments displace the share of other non-wage goods and services.

In the context of Bangladesh, there are a few studies in this field where most of them are tested the Wagner's or Keynesian law. By using the Granger causality test on the annual data of 1980 to 2014 Amin and Jannat (2017) found no causal association between government expenditure and national income in Bangladesh. They recommended that any policy regarding national income could not affect the government expenditure of Bangladesh. A relatively important study on government expenditure was passed out by Kalam and Aziz (2009) in the context of Bangladesh. The result of this study provides an indication in favor of Wagner's theory in the short run as well as in the long term. By using Bangladesh data from 1976 to 2007, they found a cointegration relation among real government expenditure, real GDP and the population size where the size of government 
expenditure positively associated with the real GDP, per capita GDP and the population size. Rana (2014) empirically estimate the relationship between economic growth and government expenditure in Bangladesh for the period of 1972 to 2012. By using the vector error correction model, this study finds a significant long-run relationship between government expenditure and economic growth in Bangladesh. To the best of authors Knowledge, there is no study till now to address the factors which determine the government expenditure of Bangladesh. This study empirically investigates the factors which can play a role to assess the government expenditure of Bangladesh.

\section{An Overview of Government Expenditure in Bangladesh}

Government expenditure generally indicates public expenses on commodities and services, and it is a noteworthy element of the GDP. According to the World Bank definition government expenditure applies to the current expenditure and investment to satisfy the various social and political needs by the central authority of a country. It also consists of the expense for national defense (except military spending) and social security. All over its defined the annual government budget although there is a considerable distinction between the approved budget and implemented budget. With some limitations and constraints, Bangladesh economy achieves remarkable growth in the last few decades. The GDP growth rate is expanded in 7.11\% in 2016. From 1994 to 2016 it recorded an average growth rate of 5.69\%. Now it's become a likely trade destination in South Asia. In World Economic Outlook 2015 of IMF registered Bangladesh as $56^{\text {th }}$ largest economy in the earth regarding the GDP of USD 186.6 billion in 2014.

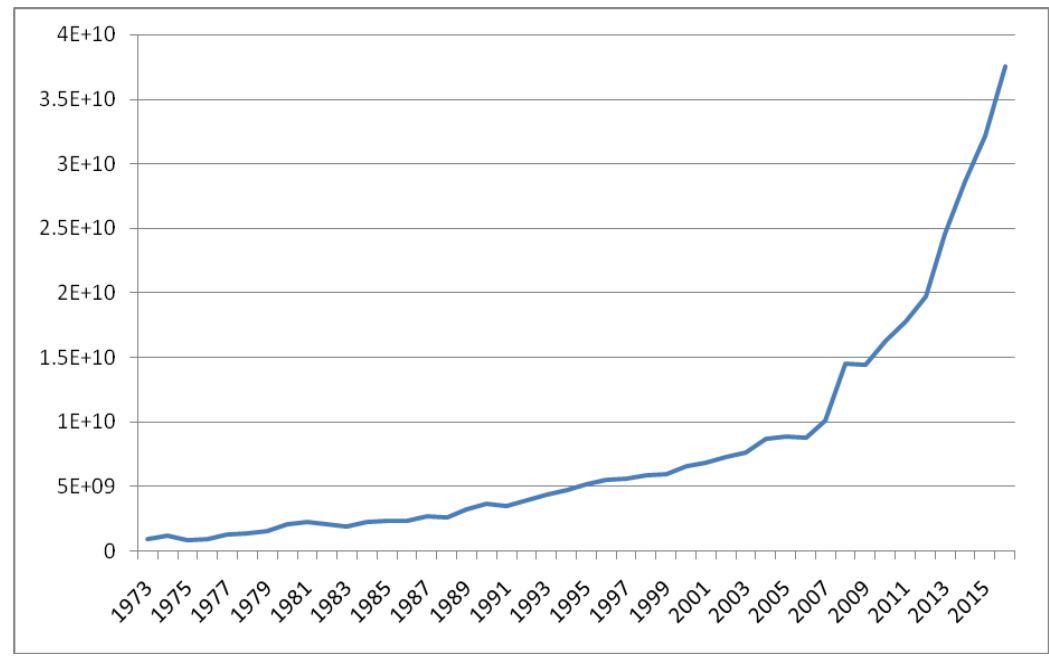

Figure1. Feature of government expenditure

Government expenditure of Bangladesh tends to upward from its beginning. Its first expenditure published in 1972-73 budget which was Tk. 786(cr.) and in 2016 its expense is Tk.290 100 (cr.). National income of Bangladesh in 2013 was $289 \%$ of the national income of 2004, and the government expenditure of 2013 was 438\% of 2004 (Amin, Jannat, 2017). The increase in government expenditure is much higher than the national income. Figure 1 shows the feature of government expenditure in constant US \$. Here each financial year considers as specific one year, for example, 1972/73 fiscal year regarded as the year of 1972.

Figure 1 depicts that government expenditure rose steadily from 1973 to 2016 in Bangladesh. Government expenditure increased at an approximately steady rate from 19801999 where year to year changeability of expenditure was significantly smaller. After those decades in the 2000s, expenditures increased further stridently. In 2008-09 government spending was constant \& after that expenditure increase in increasing manner till 2016. In 2016, government expenditure was US\$ 37518934284.

\section{Data, Methodology, and Model}

\subsection{Data Characteristics}

In line with the review of the existing literature and data availability the general model of the study can be specified in the following way:

Government Expenditure $=f($ External Debt, Dependency on Foreign Aid, GDP, Trade Openness, Urbanization, Government Revenue) 
Where,

- Government expenditure consists of all government utilization (consumption, investment, and transfer payments).

- External debt indicates the funds borrowed from a source outside the country which is expressed to the percentage of GDP. External debt has to be compensated in the exchange in which it is rented. The study shows, the relationship between external debt and government expenditure are positive and significant.

- Dependency on foreign aid which can be calculated by the ratio of net bilateral aid flow from DAC Donors to the gross national product. The expected reliance on aid inflow is ambiguous. It depends on whether aid inflows are usually utilized on the intended programme or diverted into private consumption. In this study, the perspective expectation is the dependency on foreign aid has a positive impact on government expenditure, though the effects can be rather small.

- Gross Domestic Production (GDP) is the real gross domestic product of a nation that produces in a nation's boundary. It shows the market size of a country. In this study, it is expected to have a positive correlation between GDP and government expenditure.

- Trade openness or international trade may suggest that the corresponding country is adopting some favorable trade and exchange rate policies. The ratio of the total volume of trade to GDP used as a proxy of trade openness. A positive and significant effect of trade openness on government expenditure is expected, and a more open economy attracts higher levels of government expenditure.

- Urbanization or urban population is another determinant which can be measured by the percentage of urban population to total population. It is expected that the urbanization has a positive impact on government expenditure.

- Government revenue is representing all tax and nontax revenue received by the government. This is an essential instrument of the fiscal strategy of the government. Government revenue and government expenditure positively related with each other. If government revenue increase than the government will be more enthusiastic to increase their expenditure.

This study uses the annual time series data, and all the data of these variables except government expenditure and government revenue are collected from the World Development Indicators (2017) of the World Bank for Bangladesh cover the period 1973 to 2016. Government expenditure data are collected from Bangladesh Government Budget Publication (1973 to 2016), and the data of government revenue are collected from the National Board of Revenue (NBR) of Bangladesh.

\subsection{Empirical Analysis}

\subsubsection{Test of Unit Roots}

A unit root test examines whether a time variable is non-stationary or carries a unit root. The existence of unit root is the null hypothesis of this test, and the alternative hypothesis is moreover the time series is stationary, trend stationery or volatile root. In this study Augmented Dickey-fuller test is applied to examine the properties of stationary of the time series. The equal and independent distribution of the residuals is the key assumption of the ADF test. First, the variables are tested at the levels of observing whether there is the presence of stationary property and the result finds out data are non-stationary. Than unit root test is carried out at the $1^{\text {st }}$ difference and the outcome asserts stationary feature of the variables.

\subsubsection{Test of Cointegration}

If the variables are stationary at first difference then there a possibility of the long-run relationship among the variables. Economically two or more variables are cointegrated if there prevails a long-run equilibrium or relation among them (Gujarati, 2009). Here we use the Engle-Granger test (1987) to check the cointegration among the variables. Cointegration finds a condition where two or more time series integrated in the same order are leaped jointly in such a technique that they cannot depart from some stability in the long-run. Therefore, there prevails one or more straight grouping of those same order time series which are stationary (or I(0)). A natural way to test whether $\mathrm{Y}_{\mathrm{t}}\left(\right.$ dependent variable) \& $\mathrm{X}_{\mathrm{it}}$ (some series of the independent variable)are co-integrated is to examine whether the errors $e_{t}=Y_{t}-\beta 0-\beta i X_{i t}($ where $i=1,2,3, \ldots)$ are stationary or not. Since $e_{t}$ is not observable, then the stationary test of the least squares residuals $\left[\hat{\mathrm{e}}_{t=} \mathrm{Y}_{\mathrm{t}}-\mathrm{b} 0-\mathrm{bi} \mathrm{X}_{\mathrm{it}}\right]$ is conducted by using the Dickey-fuller test.

For making co-integration, a long-term static model is needed, and the static equation of this study is:

Log Government Expenditure $=\beta o+\beta 1$ External Debt $+\beta 2$ Dependency on Foreign Aid $+\beta 3$ Log Real GDP $+\beta 4$ 
Trade Openness $+\beta 5$ Log Urban Population $+\beta 6$ Log Tax and Non Tax Revenue $+e_{t}$

Here some variables are transformed in logarithm to fit the data better.

\subsubsection{Error Correction Model}

Regression with cointegrated variables reflects only the long-run characteristics of the model but not measure the short-run dynamics. Undoubtedly, a superior time series model is supposed to illustrate the short-run dynamics and the long-run stability concurrently. Therefore, we now build up an error correction model (ECM). The ECM primary worn by D. Sargan and presently familiarized by Eagle and Granger adjusts the fluctuation of error terms (Gujrati, 2003). The ECM then an illustration of the short-run dynamic affiliation among the variables in which the error correction term assimilates the extensive run data into the model, and this indicates that the error correction expression will be momentous if cointegration exists.

The short-run dynamic equation for the previous static model can be written in the following form:

$\triangle$ Log Government Expenditure $=\gamma_{0}+\gamma_{1} \Delta$ External Debt $+\gamma_{2} \Delta$ Dependency on Foreign Aid $+\gamma_{3} \Delta$ Log Real

$G D P+\gamma_{4} \Delta$ Trade Openness $+\gamma_{5} \Delta$ Log Urban Population $+\gamma_{6} \Delta$ Log Tax and Non Tax Revenue $+\delta e_{t .-1}+v_{t}$

An error correction model was developed to calculate the momentum at which the dependent variable goes back to equilibrium following an altar in the independent variables. However, a prerequisite for developing an ECM was to check the long-run relationship among the variables included in the model.

So we can summarize this section in 3 points:

1). Examine the stationary and get the order of integration of the variables.

Continue if all the time series follow the same order of integration.

2). Check the existence of cointegration.

Advance further if there exists the cointegration.

3). Construct error correction model to confine long-run relationship and short-run dynamics.

\section{Empirical Findings}

\subsection{The Result of Stationary and Cointegration Test}

Table 1 depicts the results of the ADF unit root test. It is noticeable from the table that at level (with intercept or intercept and trend) all the variables show the characteristics of non-stationary time series. As the p-value is larger than 0.05 , then the null hypothesis of the unit root cannot be discarded. But at the $1^{\text {st }}$ difference of the all variables, the scenario is the complete opposite. The p-value is less than 0.05 that's why the null hypothesis of the unit root can be discarded. So, all the variables included in this study are integrated into order one.

Table 1. Results of ADF for unit roots

\begin{tabular}{|c|c|c|c|c|c|}
\hline \multirow[t]{2}{*}{ Variables } & \multicolumn{2}{|c|}{ Level } & \multicolumn{2}{|c|}{$1^{\text {st }}$ difference } & \multirow[t]{2}{*}{ Integration order } \\
\hline & With intercept & Intercept \& trend & With Intercept & Intercept \& trend & \\
\hline \multirow[t]{2}{*}{ Log government expenditure } & 0.8230 & -1.7289 & -7.1328 & -7.3967 & $\mathrm{I}(1)$ \\
\hline & $(0.9933)$ & $(0.7210)$ & $(0.00)$ & $(0.00)$ & \\
\hline \multirow[t]{2}{*}{ External debt } & -0.0328 & -1.7391 & -7.8069 & -7.8682 & $\mathrm{I}(1)$ \\
\hline & $(0.9564)$ & $(0.7163)$ & $(0.00)$ & $(0.00)$ & \\
\hline \multirow[t]{2}{*}{ Dependency on foreign aid } & -1.1618 & -1.9555 & -9.9209 & -9.8747 & $\mathrm{I}(1)$ \\
\hline & $(0.6817)$ & $(0.6075)$ & $(0.00)$ & $(0.00)$ & \\
\hline \multirow[t]{2}{*}{ Log GDP } & 2.9169 & -0.2967 & -8.2961 & -13.579 & $\mathrm{I}(1)$ \\
\hline & $(1.00)$ & $(.9883)$ & $(0.00)$ & $(0.00)$ & \\
\hline \multirow[t]{2}{*}{ Trade openness } & -1.0144 & -2.7078 & -3.2726 & -3.6021 & $\mathrm{I}(1)$ \\
\hline & $(0.7398)$ & $(0.2387)$ & $(0.024)$ & $(0.044)$ & \\
\hline \multirow[t]{2}{*}{ Log urban population } & -2.1251 & -2.3441 & -3.2303 & -2.5239 & $\mathrm{I}(1)$ \\
\hline & $(0.2362)$ & $(0.072)$ & $(0.025)$ & $(0.038)$ & \\
\hline \multirow[t]{2}{*}{ Log tax \& non tax government revenue } & -1.3236 & -3.1077 & -6.3099 & -6.1346 & $\mathrm{I}(1)$ \\
\hline & $(0.6101)$ & $(0.1175)$ & $(0.00)$ & $(0.0000)$ & \\
\hline
\end{tabular}

Note. Values in the bracket '( )' indicate the p-value of the corresponding statistics.

Cointegration test allows estimating the long-run coefficients or equilibrium in the process with the variables which are integrated in the same order. Results of the co-integration test are given in Table 2. 
Table 2. Result of the cointegration test

\begin{tabular}{lccc}
\hline \multicolumn{2}{c}{ Null hypothesis: residuals do not show the characteristics of stationary series at level } \\
\cline { 2 - 3 } Variable & \multicolumn{2}{c}{ Level } & Integration order \\
\cline { 2 - 3 } & With intercept & Intercept \& trend & \\
\hline Residual & -5.913205 & -5.8403 & $\mathrm{I}(0)$ \\
& $(0.00)$ & $(0.00)$ & \\
\hline
\end{tabular}

Note. Values in the bracket ' ( )' indicate the p-value of the corresponding statistics.

For testing cointegration, the Engle-Granger method is used which first construct the residual series based on the static regression. By using the ADF test, this method checks the stationary of the residuals. The results of Table 2 show that the residual is stationary at level or $\mathrm{I}(0)$. The conclusion would be that the estimated error term is stationary and therefore the variables despite being individually not stationary are cointegrated.

\subsection{Short-Run and Long-Run Determinants of Government Expenditure}

Table 3. Result of the error correction model

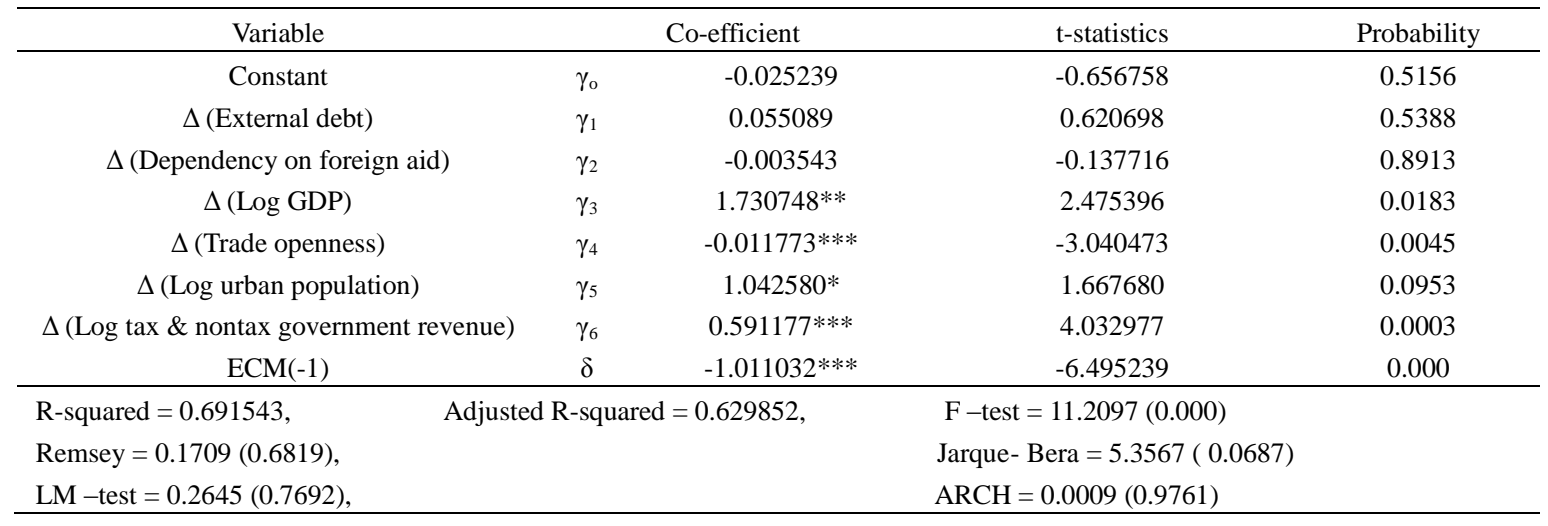

Source: Authors calculation in Eviews 8.

Note. ${ }^{*} \rightarrow 10 \% ; * * \rightarrow 5 \% ; * * * \rightarrow 1 \%$ (significance level).

Table 4. Results of long-run static model

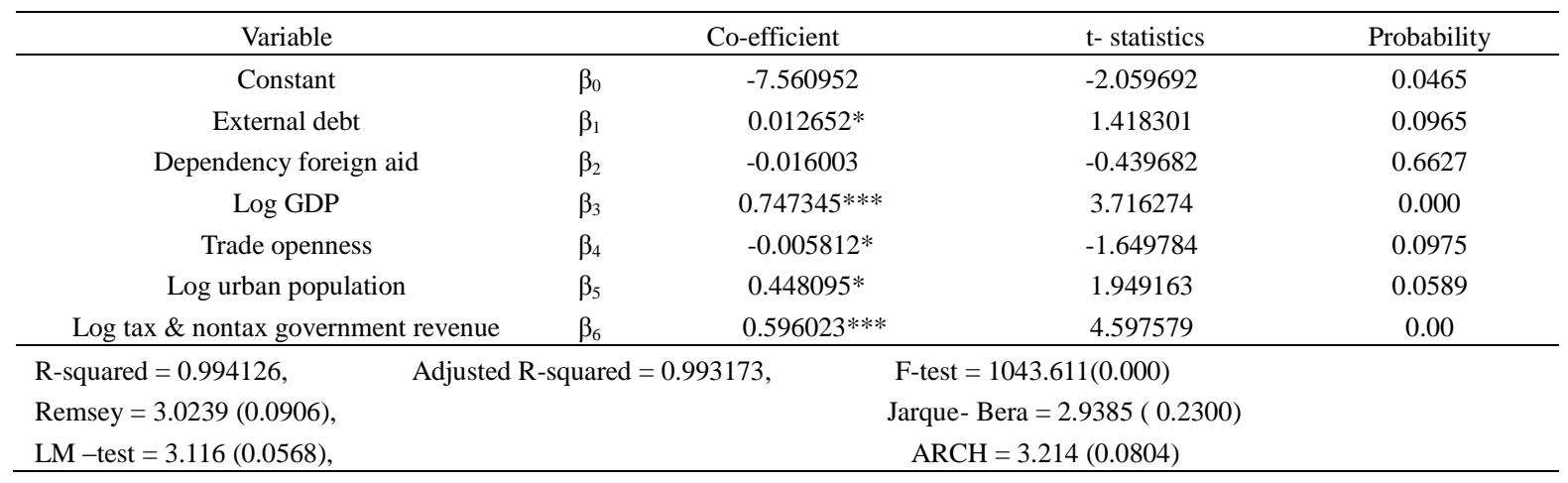

Source: Authors calculation in Eviews 8 .

Note. $* \rightarrow 10 \%$;* $\rightarrow 5 \%$; ** $\rightarrow 1 \%$ (significance level).

Table 3 and Table 4 show the result of the short run error correction model and the long run static equation respectively. After analyzing these results, it is found that some variables are momentous in the short term and some for the long term. External debts positively prompt the government expenditure in both periods. But this is not statistically significant for the short run. In the long term, a one unit increases in external debt leads to a 1.26 percent increase in the government expenditure when other variables remaining unchanged. The relationship between dependency on foreign aid and government expenditure is negative which was positively predict in the earlier section. Usefulness of assistance depends on the strong institutional set up of a country. A large amount of aid can be useless with the weak institution, and it creates difficulties in the government reform system. The foreign assistance of Bangladesh is fetching more spirited, and it's receiving reliant upon accomplishment of 
development programs and above operation. That can be a reason why our model shows the negative relationship between dependency on foreign aid and government expenditure. But the finding is foreign aid does not determine the size of the government expenditure significantly either in the short-run or the long- run. Real GDP positively identify the size of the government expenditure in both periods which implies that the boost in national output will routinely enlarge the size of the government expenditure. Therefore, this study supports the Wagner's hypothesis in the economy of Bangladesh, and this is in line with the results reported in Amin and Jannat (2017), Rana (2014) and Kalam and Aziz (2009). All other things being equal in the short-run one percent increase of the GDP increase the government expenditure 1.73 percent which is statistically noteworthy at 5 percent level and for the long-run, this percentage is 0.74 which is highly significant at 1 percent level. The nature of the relationship between trade openness (trade volume to GDP ratio) is negative which was decisive in the earlier prediction of this study. The higher level of trade openness leads to creating the higher level of privatization that influences the developing country to enter into the international market which decreases the importance of the public sector in a developing country like Bangladesh. It can be the reason for the negative relationship. A similar finding reported in Turan and Karakas (2016) in Turkey. Our result depicts if other variable being constant, one unit increases in trade openness leads to a decrease of the government expenditure 1.2 percent and 0.5 percent in the short term and the long-term correspondingly. This variable is statistically momentous at 1 percent level in the short term and 10 percent level in the long term. Urbanization (urban population) is positively related with the government expenditure, and it is significantly diverse from zero at 10 percent level in both periods. All things being considered the same a one percent growth of the urban population raise the government expenditure approximately 1 percent in the short term and for the long-term this percentage is 0.5 . Government revenue (tax and nontax) is also expanding the public expenditure which is highly significant at 1 percent level in both periods. Specifically, a one percent enhancement in the government revenue will create a 0.6 percent (approximately) increment of the government expenditure in any period.

The results in Table 3 shows that the coefficient of the ECM (-1) term is -1.011 which is statistically significant with the expected sign. It is further ensuring the long-run correlation between government expenditure and the regressors. If the error correction expression ECM (-1) is significant, then the variables go back to the equilibrium in faster rate may be in one shock (Bahram\&Pesaran, 2009). In our model, 101\% of the disequilibrium of the earlier year adjusts to the equilibrium in the present year.

$\mathrm{R}$-squared and adjusted R-squared is high (more than 90\%) for the long run static but not so for error correction model. It implies that explanatory variables in the long run equation are correlated. Usually, GDP and urbanization; external debt and trade openness are connected. But it is known to all that multicollinearity is not a severe problem if it is not exact.

However, it is observed that regardless of the period short or long external debt, GDP, urban population and government revenue positively influence the government expenditure when dependency on foreign aid and trade openness negatively affect it. It is also be inferred that in the long-term external debts be able to raise the government expenditure significantly, but in the short period, its effect is not significant at all.

The last two rows of Table 3 and Table 4 depict the results of the different diagnostic tests to test the reliability of the models. The diagnostic tests show that both models are free from any severe econometric problem. The Ramsey tests and normality tests through Jarque-Bera statistics reveal that both models are right functional form and residuals are normally distributed. There are no facts of heteroskedasticity because the ARCH's are insignificant at 5 percent significant level. Further LM tests depict that both models are free from serial correlation. Therefore, the estimated error correction model and long-run static model are reliable.

\subsection{Stability Test}

CUMSUM test is applied to assess the parameter structural stability which is structured on a plotting line of the sum of the recursive residuals. If the plotting line goes outside of the critical bound, then there exists a structural break. 


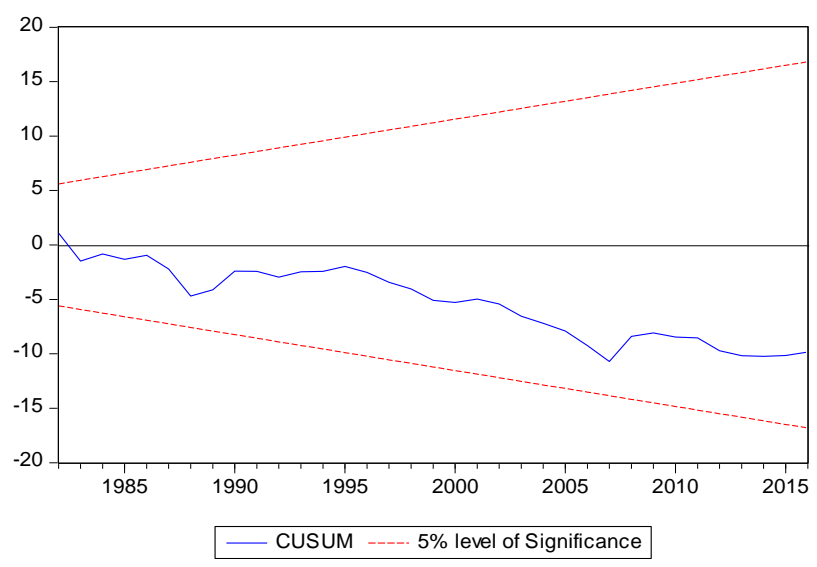

Figure 2. CUSUM test for short-run model

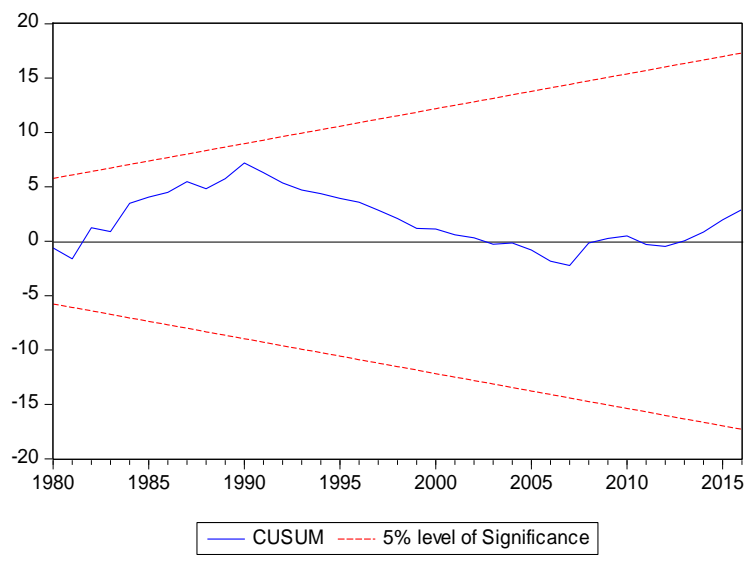

Figure 3. CUSUM test for long-run equation

Figure 2 and Figure 3 show the result for the CUMSUM test for the short-run model and long-run model respectively. The results depict the stability of the models' coefficients as the estimated CUSUM line falls within the bounds of the critical line at 5\% significant level. Therefore, the estimated coefficients are stable over the sample period for Bangladesh.

\section{Conclusion}

The primary purpose of this study is to see the determinants which determine the size of the government expenditure. The paper focuses on the economy of Bangladesh and has utilized the data covering the period 1973 to 2016. The empirical analysis based on the error correction model and long-run static through the ordinary least square method.

The study finds that GDP, trade openness, the rate of urbanization, tax and nontax revenue and external debt mainly determine the size of government expenditure regardless the time, is it short or long in case of Bangladesh. Higher government revenue significantly enhances the size of government expenditure. Therefore establishing the government expenditure, the revenue base can be expanded beyond indirect tax (value added tax) to include other direct taxes (proportional income tax) which could strengthen the core of revenue. This study also approves Wagner's hypothesis that growth of GDP significantly boosts the size of government expenditure. Therefore, the paper recommends that the private-public investment gap should be reduced to generate more employment which can speed up the growth of the national income or GDP.

It is moreover found that dependency on foreign aid cannot affect the government in any period short or long. That's why Bangladesh government can avoid foreign assistance to fulfill the budget deficit. Another finding of this study is external debt cannot affect the government expenditure significantly in the short term, but its result is significant in the long term. Hence, the government of Bangladesh should be more cautious about long-term debt burden; to make the payment of interest government will be more dependent on external debt. Finally, trade openness negatively influences public spending. Underlying causes are hard to pin down; however trade openness increase the privatization which may decrease the importance of the public sector. Besides, the composition of export and import, measurement issues and data related problem may be the possible cause.

\section{References}

Akitoby, B., Clements, B., Gupta, S., \& Inchauste, G. (2006). Public spending, voracity, and Wagner's law in developing countries. European Journal of Political Economy, 22(4), 908-924. https://doi.org/10.1016/j.ejpoleco.2005.12.001

Amin, S. B., \& Jannat, F. T. (2017). Relationship between Government Expenditure and National Income: The Case of Bangladesh. Journal of Accounting, 7(1).

Bahram, P., \& Hashem Pesaran, M. (2009). Time Series Econometrics using Microfit 5.0: A User's Manual. Oxford University Press.

Bank, B. (2017). Annual Report 2015-2016. Dhaka: Bangladesh Bank.

Chang, T. (2002). An econometric test of Wagner's law for six countries based on cointegration and error-correction modelling techniques. Applied Economics, 34(9), 1157-1169. https://doi.org/10.1080/00036840110074132 
Dani, R. (1998). Why Do More Open Economies Have Bigger Governments? Journal of Political Economy, 106(5), 997-1032. https://doi.org/10.1086/250038

Downs, A. (1957). An economic theory of political action in a democracy. Journal of political economy, 65(2), 135-150. https://doi.org/10.1086/257897

Folster, S., \& Henrekson, M. (2001). Growth effects of government expenditure and taxation in rich countries. European Economic Review, 45(8), 1501-1520. https://doi.org/10.1016/S0014-2921(00)00083-0

Gujarati, D. N. (2009). Basic econometrics: Tata McGraw-Hill Education.

Islam, A. M. (2001). Wagner's law revisited: cointegration and exogeneity tests for the USA. Applied Economics Letters, 8(8), 509-515. https://doi.org/10.1080/13504850010018743

Kalam, M., \& Aziz, N. (2009). Growth of Government Expenditure in Bangladesh: An Empirical Enquiry into the Validity of Wagner's Law (Vol. 9). https://doi.org/10.2202/1524-5861.1451

Keynes, J. M. (2018). The general theory of employment, interest, and money. Springer. https://doi.org/10.1007/978-3-319-70344-2

Kimakova, A. (2009). Government size and openness revisited: the case of financial globalization. Kyklos, 62(3), 394-406. doi:10.1111/j.1467-6435.2009.00442.

Kolluri, B. R., Panik, M. J., \& Wahab, M. S. (2000). Government expenditure and economic growth: evidence from G7 countries. Applied Economics, 32(8), 1059-1068. https://doi.org/10.1080/000368400322110

Lamartina, S., \& Zaghini, A. (2011). Increasing Public Expenditure: Wagner's Law in OECD Countries. German Economic Review, 12(2), 149-164. https://doi.org/10.1111/j.1468-0475.2010.00517.x

Mahdavi, S. (2004). Shifts in the composition of government spending in response to external debt burden. World Development, 32(7), 1139-1157. https://doi.org/10.1016/j.worlddev.2004.01.011

Nyamongo, M. E., Sichei, M. M., \& Schoeman, N. J. (2007). Government revenue and expenditure nexus in South Africa. South African Journal of Economic and Management Sciences, 10(2), 256-269. https://doi.org/10.4102/sajems.v10i2.586

Rana, R. H. (2014). Government Expenditure and Economic Growth in Bangladesh: An Empirical Study. The International Journal of Business \& Management, 2(10), 271.

Remmer, K. L. (2004). Does Foreign Aid Promote the Expansion of Government? American Journal of Political Science, 48(1), 77-92.

Turan, T., \& Karakas, M. (2016). The Effect of Trade Openness and Income on the Size of a Government. Transylvanian Review of Administrative Sciences, 15.

Ukwueze, E. R. (2015). Determinants of the Size of Public Expenditure in Nigeria. SAGE Open, 5(4). https://doi.org/10.1177/2158244015621346

Wagner, A. (1892). Grundlegung der politischen Ökonomie (Vol. 1). CF Winter.

\section{Copyrights}

Copyright for this article is retained by the author(s), with first publication rights granted to the journal.

This is an open-access article distributed under the terms and conditions of the Creative Commons Attribution license (http://creativecommons.org/licenses/by/4.0/). 